\title{
Simple and Cost-effective Synthesis of $\mathrm{Co}_{3} \mathrm{O}_{4}$ Modified GCE Electrode for $\mathrm{C}_{6} \mathrm{H}_{6} \mathrm{O}$ Detection with Unique Lamellar Structure
}

\author{
Riya Jin* Xiaojian Wang, Yuanyuan Wu, Jinming Liu, Kun Wang, Ying Wang \\ School of Environmental and Safety Engineering, North University of China, Taiyuan, 030051, China \\ *E-mail: jrya@ nuc.edu.cn
}

doi: $10.20964 / 2018.11 .91$

Received: 7 July 2018 / Accepted: 5 September 2018 / Published: 1 October 2018

\begin{abstract}
Herein, we present a simple and cost-effective strategy to prepare $\mathrm{Co}_{3} \mathrm{O}_{4}$ modified glassy carbon electrode $\left(\mathrm{Co}_{3} \mathrm{O}_{4} / \mathrm{GCE}\right)$. The unique lamellar structure of $\mathrm{Co}_{3} \mathrm{O}_{4}$ is prepared by a hydrothermal process and characterized by XRD and SEM. Then, the as-prepared $\mathrm{Co}_{3} \mathrm{O}_{4} / \mathrm{GCE}$ is utilized for $\mathrm{C}_{6} \mathrm{H}_{6} \mathrm{O}$ detection and electrochemical performance is measured by cyclic voltammetry and electrochemical impedance spectroscopy. The electrochemical measurements are used to characterize the electron transport at the solution-electrode interface. Through the use of square wave voltammetry, the electrochemical response of $\mathrm{C}_{6} \mathrm{H}_{6} \mathrm{O}$ on $\mathrm{Co}_{3} \mathrm{O}_{4}$ modified was significantly increased in $0.1 \mathrm{M}$ phosphate buffer solution ( $\mathrm{pH}$ 5.8). The proposed electrode has shown a linear relationship in the concentration range of $3.3 \mu \mathrm{M}$ to $33 \mu \mathrm{M}$, with a $\mathrm{C}_{6} \mathrm{H}_{6} \mathrm{O}$ detection limit of $2.03 \times 10^{-6} \mathrm{M}$ and sensitivity of $0.67 \mu \mathrm{A}$ $\mu \mathrm{M}^{-1}$. Moreover, the as-prepared $\mathrm{Co}_{3} \mathrm{O}_{4}$ has shown excellent repeatability and stability, which make it an ideal choice for the replacement of other costly electrode systems.
\end{abstract}

Keywords: Lamellar stacking structure; $\mathrm{Co}_{3} \mathrm{O}_{4}$; Electrochemical determination; $\mathrm{C}_{6} \mathrm{H}_{6} \mathrm{O}$

\section{FULL TEXT}

(C) 2018 The Authors. Published by ESG (www.electrochemsci.org). This article is an open access article distributed under the terms and conditions of the Creative Commons Attribution license (http://creativecommons.org/licenses/by/4.0/). 